\title{
READING SHAKESPEARE'S MIND
}

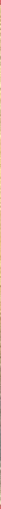

STEVE SOHMER 


\section{Reading Shakespeare's mind}

\section{MANCHESTER 1824}

Manchester University Press 
Steve Sohmer - 9781526137104

Downloaded from manchesterhive.com at 04/26/2023 11:14:20AM 


\section{Reading \\ Shakespeare's mind}

Steve Sohmer

Manchester University Press 
Copyright @ Steve Sohmer 2017

The right of Steve Sohmer to be identified as the author of this work has been asserted by him in accordance with the Copyright, Designs and Patents Act 1988.

This electronic version has been made freely available under a Creative Commons (CCBY-NC-ND) licence, thanks to the support of Knowledge Unlatched, which permits non-commercial use, distribution and reproduction provided the author(s) and Manchester University Press are fully cited and no modifications or adaptations are made. Details of the licence can be viewed at https://creativecommons.org/licenses/bync-nd/3.0/

Published by Manchester University Press

Altrincham Street, Manchester M1 7JA

www.manchesteruniversitypress.co.uk

British Library Cataloguing-in-Publication Data

A catalogue record for this book is available from the British Library

Library of Congress Cataloging-in-Publication Data applied for

ISBN 9781526113276 hardback

First published 2017

The publisher has no responsibility for the persistence or accuracy of URLs for any external or third-party internet websites referred to in this book, and does not guarantee that any content on such websites is, or will remain, accurate or appropriate.

Typeset in 10/12 Sabon by Servis Filmsetting Ltd, Stockport, Cheshire 